\title{
Mentoring Undergraduate Researchers: Faculty Mentors' Perceptions Of The Challenges And Benefits Of The Research Relationship
}

Sharyn J. Potter, Ph.D., M.P.H., University of New Hampshire, USA

Eleanor Abrams, Ph.D., University of New Hampshire, USA

Lisa Townson, Ph.D., University of New Hampshire, USA

Julie E. Williams, Ph.D. University of New Hampshire, USA

\begin{abstract}
In the past decade, college and university officials have tried to formalize avenues that provide undergraduate students with opportunities to conduct research, either in direct collaboration with a faculty member or as independent research under the supervision of a faculty member. Administrators and faculty have worked to institutionalize these programs because they recognize the intrinsic benefits of these faculty student collaborations. Since most faculty balance a wide range of demands, we wanted to understand how faculty members view these partnerships in the larger context of their work. In 2008, as the Undergraduate Research Conference at our midsize public New England University entered its ninth year, the evaluation committee administered a survey to examine faculty members' attitudes toward undergraduate research endeavors. Our results show that faculty felt overwhelmingly positive about their role as mentors. Full professors indicate more satisfaction in this role than associate and assistant professors.
\end{abstract}

Keywords: Mentoring, Faculty, Undergraduate Research

\section{INTRODUCTION}

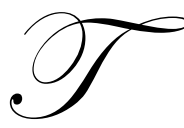

he Boyer Commission Report (1998) was one of the first national position papers to state strongly that research universities should make research-based learning a part of the undergraduate curriculum. The Commission outlined a 10 point plan to improve undergraduate education. The first point in the report recommends that institutions of higher education redesign their curricula so research-based learning is the standard. Students should learn from scholar-teachers who are prepared to structure their courses so students learn by discovery guided by mentoring rather than by the transmission of knowledge. The other nine points of the Commission's plan flow from this first point; the rest of the report discusses how the undergraduate experience could be designed around a learning community model. One of the leverage points stated in the report is to change the faculty reward system from using only research as the gold standard for faculty excellence to an expanded one in which the criteria of quality include inquiry-based, student-oriented teaching.

During that same time period, the National Research Council (Schowen, 1998) and the National Science Foundation (2000) expressed the belief that undergraduate research needs to be a critical component of an undergraduate education. In response to this united call for action, there now is an effort to encourage undergraduates to engage in research and scholarship - either working on independent research projects or, more often, as an "apprentice" on a faculty member's ongoing research project.

Since those seminal reports, research has shown that undergraduate students benefit from their research experiences in several ways (Collins, 2006; Lopatto, 2003; Potter et al., in review). Students who conduct and 
present research experience what it would be like to be a professional in their chosen field as they interact with faculty members and colleagues with similar interests (Collins, 2001; Lopatto; 2003). In fact, Collins (2001) found that research experience, presentations, and publications are valued by employers and graduate schools. In a study of clinical psychology programs, graduate admission directors indicated that research experience or a commitment to research was the most important factor in determining admittance (Munoz-Dunbar \& Stanton, 1999).

In addition, the undergraduate research experience often facilitates the development of positive mentoring relationships between faculty and student. Previous research on faculty mentoring showed that, in a mentoring relationship, an experienced professional trains the newcomer about profession or discipline specific practices, expectations and norms (Waldeck, Orrego, Plax, \& Kearney, 1997; Folse, 1991; Ekrut \& Mokros, 1984). The relationship that develops in faculty - student research collaborations not only results in motivation for students to pursue a job or graduate school, but also provides them with the personal contacts often required to open doors to other opportunities beyond graduation (Potter et al., in review). While the benefit to the student's learning is firmly established, what is less clear is how this relationship impacts the faculty mentor. In fact, the existing research findings are mixed (Hattie and Marsh, 1996; Braxton, 1996; Marsh \& Hattie, 2002).

There is a strong belief that the relationship between research and teaching can be highly beneficial for faculty members at an institution of higher education (Jenkins et al., 2007). Faculty who work with students in undergraduate research partnerships stated they have a better understanding of what motivates students to learn and are better able to tailor their courses to meet the needs and interests of their students (Jenkins et al., 2007). However, other research indicates that the two endeavors are unrelated. Hattie and Marsh, in a meta-analysis of existing research on the nexus of teaching and research, argued that "the common belief that teaching and research were inextricably intertwined is an enduring myth" (1996, p. 529). Their conclusion was based on 58 articles contributing 498 correlations; the overall correlation was 0.06 (see also Feldman, 1987). They also searched for mediators and moderators to this overall correlation, with little success. The overall conclusion of 'there is no relation' was found across disciplines, various measures of research output (e.g., quality, productivity, citations), various measures of teaching quality (student evaluation, peer ratings), and different categories of university (Liberal Arts, research). In fact, in later research (2002), they found that teaching effectiveness and research productivity are nearly uncorrelated.

Many faculty have significant concerns regarding the time, financial commitment, and the overall benefit to them professionally of the effort required to mentor undergraduate students through the research process effectively (Zydney, 2002; Hakim, 1998). The faculty members in one study felt that undergraduates did not make significant research contributions during their involvement on faculty's research projects, particularly when balanced against the amount of time that the faculty mentor had invested in the students (Foertsch et al., 1997).

In spite of the barriers, many faculty members do mentor undergraduate students through research projects. In a survey of 155 science and engineering faculty at a mid-size university with an extensive undergraduate research program, faculty rated the desire to influence the careers of talented young students as one of the primary motivating factors to mentor students engaging in undergraduate research (Zydney, 2002). To a lesser degree, faculty stated that undergraduates could contribute to the faculty's research and that the undergraduates sometimes influenced the faculty's thinking about the research project. A less important, but significant, reason was the faculty felt that the undergraduates contributed to the faculty members' quality of life at the university. While this research identified some positive reasons to become involved in mentoring students in the sciences, it is not known if those incentives are the same across all scholarly disciplines.

Several research studies have found that faculty members state they mentor undergraduate students through a research project because they feel a research experience(s) is a necessary part of the education of an undergraduate (Monte, 2001; Gafney, 2005). Faculty have stated that they will supervise undergraduate research because the undergraduates eagerly ask to become involved in research; that excitement has stimulated faculty to mentor undergraduate research experiences, especially if the institution does not have graduate students (Lancy, 2003).

The existing research on faculty mentoring of undergraduate students is comprised of disciplinary-specific studies asking a small number of faculty about the reasons they mentor students. The study reported here will 
further this research by examining the practices and perceptions of faculty campus-wide who were actively involved in undergraduate research (UR) at the University of New Hampshire (UNH) -- why they mentor undergraduate students and what their perceptions are of the rewards and barriers of doing so.

UNH is a land, sea and space grant, public university, classified by the Carnegie Foundation as a research high activity, community engaged institution. There are approximately 12,000 undergraduate and 2, 200 graduate students enrolled in 6 colleges. External funding for research in 2008 was $\$ 99$ million and undergraduates are actively engaged in a range of faculty research. Participation in the campus-wide Undergraduate Research Conference has grown from approximately 100 students in 2000 to over 800 students in 2008 . The site was selected because the university is committed to research excellence and the interest in undergraduate research is growing.

\section{RESEARCH QUESTIONS}

The purpose of this research was to determine what factors motivate the faculty to participate in undergraduate research, and to understand the nature of the work faculty and undergraduates engage in during an UR experience. We also were interested to see if there were any differences across discipline, rank, or gender of the faculty members.

The specific research questions addressed were:

(1) How much time do faculty spend mentoring students for UR and how is this time spent (e.g., in face-toface meetings, in the lab/field, etc). Does this use of time differ by the gender and rank of the faculty?

(2) How do members of the faculty perceive the relationship between their role as UR mentors and their research? Do perceptions of this relationship vary by the gender and rank of the faculty?

(3) What impact does faculty perceive UR to have on their relationship with students? Do views of this relationship vary by the gender and rank of the faculty?

(4) Do faculty members see a connection between UR mentoring and their professional and personal development, and does this vary by faculty gender and rank?

\section{BACKGROUND OF THE UNDERGRADUATE RESEARCH CONFERENCE}

The ninth annual UNH Undergraduate Research Conference (URC) took place in 2008. More than 800 students participated - the highest number in the event's history - at more presentation venues and with more faculty participation across the disciplines than ever before. The UNH URC is a weeklong celebration of student inquiry and creativity, featuring more than 20 events on two campuses. Depending on their discipline, UNH URC participants have opportunities to give research talks, exhibit and discuss posters, present mechanical inventions, and present their approaches to fine art, theater, and music projects.

Efforts to evaluate the impact of undergraduate research in 2006 and 2007 included surveys of current student participants and a pilot study of alumni who have participated in URC. The results of the research on student participants are documented in a forthcoming article (Potter et al., in review). In addition, a small study of fifteen faculty members who had served as mentors for the URC provide some preliminary insights into the challenges and benefits of being a faculty mentor to an undergraduate student. This pilot study encouraged us to pursue a more comprehensive evaluation of the reasons faculty members agree to become faculty mentors in an undergraduate research experience, the nature of the work engaged by faculty-student partnerships during a UR experience, and the differences, if any, in those factors across the disciplines, rank or gender.

\section{METHODS}

\section{Survey Construction}

The on-line survey administered to URC faculty mentors was based upon the findings from the faculty pilot study administered in 2006. The short (10-minute) on-line survey had 25 short answer questions and two openended questions. The first screen asked participants for their permission to use their data in our research. Then, survey questions were presented that focused on the faculty members' experience as a mentor for the URC, 
including the number of students they had mentored and the number of years they had served as a mentor. The second part of the survey focused on the time the mentors spent with their students and how they characterized the use of this time. The third part of the survey consisted of two open-ended questions that asked faculty for their input for making changes and improvements to the URC at the University of New Hampshire. The fourth and fifth sections of the survey asked faculty to complete questions focusing on how faculty felt the URC impacted both their teaching and research endeavors. Finally, the sixth part of the survey asked faculty for basic demographic information, including gender, rank and college of their appointment.

\section{Participants}

We surveyed faculty members who had served as mentors during the 2007 conference and the three previous conferences, as these conferences were similar in administration and size. A list of faculty members was compiled from the conference programs for the four conference years which listed the name of the students, the students' home departments and the students' primary mentors. E-mail addresses were collected for the faculty members, including those who had retired or left the university. The final group of 437 faculty mentors was sent an e-mail, signed by the two members of the university faculty from the URC evaluation committee who were coordinating the evaluation efforts, inviting them to participate in a survey to obtain feedback from conference stakeholders that would be used to improve all aspects of the Undergraduate Research Conference. The email emphasized that the dedication of faculty mentors is an integral part of the research and the conference. Ten days after the first e-mail message, a follow-up e-mail was sent reminding faculty to complete the survey if they had not yet done so or thanking the faculty that had already done so. Since the web survey program tracks the computer IP address, we were able to verify that no one had completed the survey more than once. A review of the results by the administrator confirmed that each faculty name appeared only once.

Table 1: URC Mentor Demographic Characteristics

\begin{tabular}{|lr}
\hline Gender & Number \\
Male & 84 \\
Female & 54 \\
Title & \\
Assistant Professor & 20 \\
Associate Professor & 48 \\
Professor & 45 \\
Other & 25 \\
Total & 138 \\
College* & \\
College of Life Sciences and Agriculture & 31 \\
College of Liberal Arts & 22 \\
College of Engineering and Physical Sciences & 15 \\
College of Health and Human Services & \\
Thompson School of Applied Science, & 14 \\
UHN Manchester Campus, Business School & \\
Percentage of faculty member survey & 102 \\
participants whose students' who received funding & \\
& \\
Number of years taught at UNH & 14.21 \\
& \\
& \\
& \\
& \\
& \\
&
\end{tabular}




\section{RESULTS}

\section{Quantitative Analysis}

One hundred and thirty-eight current and previous Undergraduate Research Conference mentors completed the on-line survey, representing a response rate of $32 \%$. In Table 1, we present the demographic characteristics of the survey participants. Sixty-one percent of the respondents were male and 39\% were female. This response rate compares favorably to the ratio of female $(34.8 \%)$ and male $(65.2 \%)$ faculty at UNH. Fourteen percent of the respondents identified themselves as assistant professors, $35 \%$ as associate professors, $32 \%$ as full professors and $18 \%$ as research faculty or members of the administration. The participants had taught at UNH for an average of 14 years $( \pm 10$ years $)$ and represented 49 disciplines. The College of Liberal Arts had the largest number of survey participants ( $40 \%$ of the respondents).

Table 2: Time Spent by Faculty Mentors by Gender and Rank

Hours spent with mentored students

\begin{tabular}{|c|c|c|c|c|c|c|c|c|}
\hline \multicolumn{2}{|c|}{ All Faculty } & \multicolumn{2}{|c|}{ Faculty Gender } & \multicolumn{5}{|c|}{ Faculty Rank } \\
\hline Total number hours spent with eac & $\%$ & Male (84) & Female (54) & Full (45) & Associate (48) & Assistant (20) & Other $(25)$ & \\
\hline $0-10$ hours & $20 \%$ & $27 \%$ & $27 \%$ & $19 \%$ & $29 \%$ & $21 \%$ & $33 \%$ & \\
\hline $11-30$ hours & $24 \%$ & $27 \%$ & $31 \%$ & $13 \%$ & $33 \%$ & $30 \%$ & $29 \%$ & \\
\hline $31-50$ hours & $20 \%$ & $27 \%$ & $22 \%$ & $38 \%$ & $20 \%$ & $30 \%$ & $17 \%$ & \\
\hline more than 50 hours & $17 \%$ & $20 \%$ & $20 \%$ & $31 \%$ & $18 \%$ & $21 \%$ & $21 \%$ & \\
\hline \multicolumn{9}{|c|}{ Percentage of time spent in e-mail communication } \\
\hline$<10 \%$ & $53 \%$ & $57 \%$ & $46 \%$ & $35 \%$ & $41 \%$ & $71 \%$ & $64 \%$ & \\
\hline $10-30 \%$ & $37 \%$ & $35 \%$ & $43 \%$ & $55 \%$ & $45 \%$ & $24 \%$ & $28 \%$ & \\
\hline $31-60 \%$ & $9 \%$ & $8 \%$ & $11 \%$ & $10 \%$ & $14 \%$ & $4 \%$ & $8 \%$ & \\
\hline $61-90 \%$ & $0 \%$ & $0 \%$ & $0 \%$ & $0 \%$ & $0 \%$ & $0 \%$ & $0 \%$ & \\
\hline$>90 \%$ & $0 \%$ & $0 \%$ & $0 \%$ & $0 \%$ & $0 \%$ & $0 \%$ & $0 \%$ & $*$ \\
\hline \multicolumn{9}{|c|}{ Percentage of time spent in face-to-face meetings } \\
\hline$<10 \%$ & $3 \%$ & $1 \%$ & $4 \%$ & $0 \%$ & $4 \%$ & $0 \%$ & $4 \%$ & \\
\hline $10-30 \%$ & $17 \%$ & $18 \%$ & $19 \%$ & $15 \%$ & $14 \%$ & $18 \%$ & $24 \%$ & \\
\hline $31-60 \%$ & $35 \%$ & $36 \%$ & $30 \%$ & $50 \%$ & $33 \%$ & $29 \%$ & $32 \%$ & \\
\hline $61-90 \%$ & $31 \%$ & $32 \%$ & $28 \%$ & $35 \%$ & $27 \%$ & $38 \%$ & $20 \%$ & \\
\hline$>90 \%$ & $15 \%$ & $13 \%$ & $20 \%$ & $0 \%$ & $22 \%$ & $16 \%$ & $20 \%$ & \\
\hline \multicolumn{9}{|l|}{ Percentage of time spent in lab/field } \\
\hline$<10 \%$ & $53 \%$ & $50 \%$ & $61 \%$ & $35 \%$ & $63 \%$ & $56 \%$ & $44 \%$ & \\
\hline $10-30 \%$ & $23 \%$ & $24 \%$ & $20 \%$ & $35 \%$ & $16 \%$ & $18 \%$ & $32 \%$ & \\
\hline $31-60 \%$ & $15 \%$ & $16 \%$ & $11 \%$ & $20 \%$ & $14 \%$ & $16 \%$ & $12 \%$ & \\
\hline $61-90 \%$ & $9 \%$ & $10 \%$ & $7 \%$ & $10 \%$ & $6 \%$ & $9 \%$ & $12 \%$ & \\
\hline$>90 \%$ & $1 \%$ & $1 \%$ & $0 \%$ & $0 \%$ & $0 \%$ & $2 \%$ & $0 \%$ & \\
\hline
\end{tabular}

$\mathrm{p}$-value $\mathrm{T} \mathrm{p}<.10 * \mathrm{p}<.05,{ }^{* *} \mathrm{p}<.01,{ }^{* * *} \mathrm{p}<.001$

|* $63 \%$ of the faculty reported ithat this time includes the time that they spent working

with students on honors theses, special class projects and other research projects.

Faculty use of mentoring time: In Table 2, we present the results of our analysis of the amount of time faculty mentors reported spending with the undergraduate students they mentored and how this time was spent. Faculty members were asked to estimate the amount of time they spent working with their undergraduate research students on honors theses, special class projects and other research projects that undergraduates present at the Undergraduate Research Conference. Twenty-four percent of the faculty respondents indicated that they spent between 11 and 30 
hours over the semester with each student they mentored who presented at URC; $20 \%$ reported that they spent between 31 and 50 hours during this period. These hours did not vary significantly by faculty gender or faculty rank.

We then examined how the mentoring time was spent by the faculty-student partnership. Fifty-three percent of the faculty reported that less than $10 \%$ of their time with students was spent in e-mail communication. Our chi-square analysis indicates the percentage of time spent in e-mail communication did not vary significantly by faculty gender, yet it did differ significantly by rank, with full and associate professors spending more time in e-mail communication than assistant professors and mentors in the "other" category. Sixty-six percent of the faculty reported they spent $31-90 \%$ of the time that they mentored undergraduate students in face-to-face meetings. The results of the chi-square analysis indicate that these findings do not vary significantly by faculty gender or faculty rank. Finally, when we examined the percentage of time the mentor spent with undergraduate researchers in the lab or field, we found that $53 \%$ of the faculty participants spent less that $10 \%$ of their mentoring time in this manner. These results did not vary significantly by gender or faculty rank.

How mentoring impacts faculty research program: When asked about their UR mentoring responsibilities and their own research, $44 \%$ of the faculty participants strongly agreed or agreed with the following statement, "Involvement with the URC student motivated me to do my research." Agreement with this statement did not vary significantly by faculty gender but did vary significantly by faculty rank $(\mathrm{p}<.05$; see Table 3$)$. Eighty percent of full professors strongly agreed or agreed with this statement, while $49 \%$ of associate professors and $47 \%$ of assistant professors strongly agreed or agreed with this statement.

A small number, fifteen percent of all the faculty participants, strongly agreed or agreed with the statement, "Involvement as an URC mentor hindered my ability to do research." Agreement with this statement did not significantly vary by faculty rank. However, agreement did vary by faculty gender $(\mathrm{p}<.10)$. Twenty-six percent of the female faculty members felt that being an URC mentor hindered their ability to do research while only $13 \%$ of male faculty members felt this way.

Table 3: Faculty Perceptions of How Mentoring Impacts Faculty Research Program

\begin{tabular}{|c|c|c|c|c|c|c|c|c|}
\hline & \multirow{2}{*}{$\frac{\text { All Faculty }}{\%}$} & \multicolumn{2}{|c|}{ Faculty Gender } & & \multicolumn{4}{|c|}{ Faculty Rank } \\
\hline & & Male (84) & $\underline{\text { Female }(54)}$ & & $\underline{\text { Full (45) }}$ & Associate (48) & Assistant (20) & $\underline{\text { Other }(25)}$ \\
\hline \multicolumn{9}{|c|}{ Involvement w/ URC student motivated me to do my research } \\
\hline Strongly Agree & $10 \%$ & $11 \%$ & $17 \%$ & & $25 \%$ & $8 \%$ & $7 \%$ & $24 \%$ \\
\hline Agree & $34 \%$ & $48 \%$ & $32 \%$ & & $55 \%$ & $41 \%$ & $40 \%$ & $40 \%$ \\
\hline Disagree & $21 \%$ & $26 \%$ & $28 \%$ & & $10 \%$ & $29 \%$ & $36 \%$ & $20 \%$ \\
\hline Strongly Disagree & $9 \%$ & $11 \%$ & $11 \%$ & & $0 \%$ & $16 \%$ & $13 \%$ & $0 \%$ \\
\hline Don't Know & $6 \%$ & $5 \%$ & $13 \%$ & & $10 \%$ & $601 \%$ & $4 \%$ & $16 \%$ \\
\hline \multicolumn{9}{|c|}{ Involvement as a URC mentor hinder my ability to do research } \\
\hline Strongly Agree & $2 \%$ & $0 \%$ & $6 \%$ & & $0 \%$ & $0 \%$ & $4 \%$ & $0 \%$ \\
\hline Agree & $13 \%$ & $13 \%$ & $20 \%$ & & $10 \%$ & $16 \%$ & $16 \%$ & $20 \%$ \\
\hline Disagree & $46 \%$ & $56 \%$ & $57 \%$ & & $70 \%$ & $61 \%$ & $60 \%$ & $36 \%$ \\
\hline Strongly Disagree & $17 \%$ & $27 \%$ & $13 \%$ & & $15 \%$ & $18 \%$ & $18 \%$ & $40 \%$ \\
\hline Don't Know & 2.9 & $4 \%$ & $4 \%$ & $\mathrm{~T}$ & $5 \%$ & $4 \%$ & $2 \%$ & $4 \%$ \\
\hline \multicolumn{9}{|c|}{ Mentoring for URC reduces the time I spend on research } \\
\hline Strongly Agree & $6 \%$ & $6 \%$ & $11 \%$ & & $5 \%$ & $4 \%$ & $11 \%$ & $8 \%$ \\
\hline Agree & $23 \%$ & $21 \%$ & $39 \%$ & & $35 \%$ & $33 \%$ & $27 \%$ & $16 \%$ \\
\hline Disagree & $39 \%$ & $56 \%$ & $35 \%$ & & $50 \%$ & $47 \%$ & $53 \%$ & $44 \%$ \\
\hline Strongly Disagree & $9 \%$ & $14 \%$ & $7 \%$ & & $5 \%$ & $14 \%$ & $4 \%$ & $24 \%$ \\
\hline Don't Know & $4 \%$ & $2 \%$ & $7 \%$ & $*$ & $5 \%$ & $2 \%$ & $4 \%$ & $8 \%$ \\
\hline
\end{tabular}

p-value T $\mathrm{p}<.10 * \mathrm{p}<.05, * * \mathrm{p}<.01,{ }^{* * *} \mathrm{p}<.001$ 
When faculty participants were asked how the time they spend on mentoring negatively impacts their research, $84 \%$ of the participants strongly disagreed or disagreed with the following statement, "Mentoring for URC reduces the time I spend on research." Only $16 \%$ of the faculty participants indicated that serving as an UR mentor reduced the time available for them to pursue their own research. Disagreement with this statement significantly varied by faculty gender $(\mathrm{p}<.05)$, but not by faculty rank. Forty-two percent of female and $70 \%$ of male faculty members disagreed or strongly disagreed with this statement.

Table 4: URC Mentoring and Faculty-Student Relationships

\begin{tabular}{|c|c|c|c|c|c|c|c|c|c|}
\hline & $\frac{\text { All Faculty }}{\%}$ & \multicolumn{3}{|c|}{$\begin{array}{c}\text { Faculty Gender } \\
\text { Male (84) Female (54) }\end{array}$} & \multicolumn{5}{|c|}{$\underline{\text { Faculty Rank }}$} \\
\hline \multicolumn{10}{|c|}{ I learn from my students during the URC process } \\
\hline Strongly Agree & $25 \%$ & $30 \%$ & $33 \%$ & & $35 \%$ & $31 \%$ & $18 \%$ & $52 \%$ & \\
\hline Agree & $46 \%$ & $60 \%$ & $52 \%$ & & $60 \%$ & $57 \%$ & $64 \%$ & $40 \%$ & \\
\hline Disagree & $6 \%$ & $7 \%$ & $9 \%$ & & $5 \%$ & $6 \%$ & $13 \%$ & $4 \%$ & \\
\hline Striongly Disagree & $60 \%$ & $1 \%$ & $0 \%$ & & $0 \%$ & $2 \%$ & $0 \%$ & $0 \%$ & \\
\hline Don't Know & $3 \%$ & $2 \%$ & $6 \%$ & $*$ & $0 \%$ & $4 \%$ & $4 \%$ & $4 \%$ & \\
\hline \multicolumn{10}{|c|}{ URC has helped me relate better to my students } \\
\hline Strongly Agree & $14 \%$ & $18 \%$ & $17 \%$ & & $25 \%$ & $14 \%$ & $11 \%$ & $28 \%$ & \\
\hline Agree & $42 \%$ & $54 \%$ & $48 \%$ & & $65 \%$ & $41 \%$ & $51 \%$ & $60 \%$ & \\
\hline Disagree & $12 \%$ & $14 \%$ & $17 \%$ & & $5 \%$ & $20 \%$ & $22 \%$ & $0 \%$ & \\
\hline Strongly Disagree & $4 \%$ & $2 \%$ & $7 \%$ & & $0 \%$ & $10 \%$ & $2 \%$ & $0 \%$ & \\
\hline Don't Know & $10 \%$ & $12 \%$ & $11 \%$ & & $5 \%$ & $14 \%$ & $13 \%$ & $12 \%$ & $\mathrm{~T}$ \\
\hline \multicolumn{10}{|c|}{ My students have reasonable expectations of my involvement in their URC experience. } \\
\hline Strongly Agree & $37 \%$ & $0 \%$ & $0 \%$ & & $40 \%$ & $43 \%$ & $35 \%$ & $24 \%$ & \\
\hline Agree & $55 \%$ & $0 \%$ & $0 \%$ & & $56 \%$ & $49 \%$ & $60 \%$ & $60 \%$ & \\
\hline Disagree & $1 \%$ & $1 \%$ & $0 \%$ & & $2 \%$ & $2 \%$ & $0 \%$ & $0 \%$ & \\
\hline Strongly Disagree & $1 \%$ & $0 \%$ & $0 \%$ & & $0 \%$ & $2 \%$ & $0 \%$ & $0 \%$ & \\
\hline Don't Know & $6 \%$ & $0 \%$ & $0 \%$ & & $2 \%$ & $4 \%$ & $5 \%$ & $16 \%$ & \\
\hline \multicolumn{10}{|c|}{ My students expect me to be more involved with their research than is feasible. } \\
\hline Strongly Agree & $2 \%$ & $0 \%$ & $0 \%$ & & $2 \%$ & $0 \%$ & $0 \%$ & $8 \%$ & \\
\hline Agree & $13 \%$ & $0 \%$ & $0 \%$ & & $9 \%$ & $21 \%$ & $5 \%$ & $12 \%$ & \\
\hline Disagree & $65 \%$ & $0 \%$ & $0 \%$ & & $65 \%$ & $61 \%$ & $80 \%$ & $60 \%$ & \\
\hline Strongly Disagree & $13 \%$ & $0 \%$ & $0 \%$ & & $13 \%$ & $14 \%$ & $15 \%$ & $8 \%$ & \\
\hline Don't Know & $7 \%$ & $0 \%$ & $0 \%$ & & $11 \%$ & $4 \%$ & $0 \%$ & $12 \%$ & \\
\hline
\end{tabular}

p-value T $\mathrm{p}<.10 * \mathrm{p}<.05,{ }^{* *} \mathrm{p}<.01, * * * \mathrm{p}<.001$

URC Mentoring and Faculty Student Relationships: In Table 4, the results from our chi-square analysis provide some insight as to how the mentoring experience impacts faculty student relationships. While $71 \%$ of the respondents indicated that they strongly agreed or agreed with the statement, "I learn from my students during the URC process," this sentiment varied significantly by gender, with $33 \%$ of female and $30 \%$ of male faculty strongly agreeing with the statement and $60 \%$ of male and $52 \%$ of female faculty agreeing with the statement $(\mathrm{p}<.05)$. The responses to this statement did not vary significantly by faculty rank.

Fourteen percent of all survey respondents strongly agreed and $42 \%$ of all survey respondents agreed with the statement, "URC has helped me relate better to my students." Responses to this statement did not vary significantly by faculty gender, but they did vary by faculty rank $(\mathrm{p}<.10)$. Ninety percent of the full professors 
strongly agreed or agreed with this statement, while $55 \%$ of the associate professors and $62 \%$ of the assistant professors strongly agreed or agreed with this statement.

Table 5: URC Mentoring and Faculty Personal and Professional Development

\begin{tabular}{|c|c|c|c|c|c|c|c|c|}
\hline & All Faculty & Facul & ty Gender & & & aculty Rank & & \\
\hline & $\%$ & Male (84) & Female (54) & Full (45) & Associate (48) & Assistant (20) & Other $(25)$ & \\
\hline I gain personal sati & action from & orking w/L & JRC students & & & & & \\
\hline Strongly Agree & $50 \%$ & $64 \%$ & $57 \%$ & $70 \%$ & $59 \%$ & $53 \%$ & $76 \%$ & \\
\hline Agree & $27 \%$ & $35 \%$ & $33 \%$ & $30 \%$ & $33 \%$ & $44 \%$ & $20 \%$ & \\
\hline Disagree & $60 \%$ & $0 \%$ & $2 \%$ & $0 \%$ & $2 \%$ & $0 \%$ & $0 \%$ & \\
\hline Don't Know & $3 \%$ & $1 \%$ & $7 \%$ & $0 \%$ & $6 \%$ & $2 \%$ & $4 \%$ & \\
\hline If a reduced course & bad was offer & ed I would & take it & & & & & \\
\hline Strongly Agree & $23 \%$ & $21 \%$ & $39 \%$ & $60 \%$ & $25 \%$ & $24 \%$ & $16 \%$ & \\
\hline Agree & $28 \%$ & $39 \%$ & $28 \%$ & $15 \%$ & $43 \%$ & $29 \%$ & $48 \%$ & \\
\hline Disagree & $19 \%$ & $25 \%$ & $22 \%$ & $15 \%$ & $22 \%$ & $36 \%$ & $12 \%$ & \\
\hline Strongly Disagree & $4 \%$ & $6 \%$ & $2 \%$ & $5 \%$ & $6 \%$ & $0 \%$ & $8 \%$ & \\
\hline Don't Know & $26 \%$ & $8 \%$ & $9 \%$ & $5 \%$ & $4 \%$ & $11 \%$ & $16 \%$ & * \\
\hline I have not found ar & benefits to $\mathrm{m}$ & $\mathrm{y}$ involvem & ent in URC. & & & & & \\
\hline Strongly Agree & $0 \%$ & $0 \%$ & $0 \%$ & $0 \%$ & $0 \%$ & $0 \%$ & $0 \%$ & \\
\hline Agree & $6 \%$ & $0 \%$ & $9 \%$ & $4 \%$ & $14 \%$ & $0 \%$ & $4 \%$ & \\
\hline Disagree & $34 \%$ & $40 \%$ & $43 \%$ & $53 \%$ & $37 \%$ & $40 \%$ & $36 \%$ & \\
\hline Strongly Disagree & $38 \%$ & $51 \%$ & $43 \%$ & $38 \%$ & $45 \%$ & $60 \%$ & $56 \%$ & \\
\hline Don't Know & $3 \%$ & $3 \%$ & $5 \%$ & $5 \%$ & $4 \%$ & $0 \%$ & $4 \%$ & \\
\hline Involvement as an & $\mathrm{RC}$ mentor is & an expecte & $\mathrm{d}$ part of my jo & as a facult & ty member. & & & \\
\hline Strongly Agree & $3 \%$ & $5 \%$ & $4 \%$ & $4 \%$ & $6 \%$ & $0 \%$ & $4 \%$ & \\
\hline Agree & $23 \%$ & $27 \%$ & $30 \%$ & $38 \%$ & $22 \%$ & $25 \%$ & $28 \%$ & \\
\hline Disagree & $32 \%$ & $43 \%$ & $35 \%$ & $36 \%$ & $39 \%$ & $55 \%$ & $36 \%$ & \\
\hline Strongly Disagree & $18 \%$ & $21 \%$ & $22 \%$ & $15 \%$ & $31 \%$ & $10 \%$ & $24 \%$ & \\
\hline Don't Know & $5 \%$ & $4 \%$ & $9 \%$ & $7 \%$ & $2 \%$ & $10 \%$ & $8 \%$ & \\
\hline Involvement as an & RC mentor $\mathrm{s}$ & lould be for & mally rewarde & by the uni & versity. & & & \\
\hline Strongly Agree & $16 \%$ & $16 \%$ & $24 \%$ & $11 \%$ & $18 \%$ & $35 \%$ & $24 \%$ & \\
\hline Agree & $36 \%$ & $48 \%$ & $39 \%$ & $49 \%$ & $41 \%$ & $40 \%$ & $48 \%$ & \\
\hline Disagree & $18 \%$ & $23 \%$ & $20 \%$ & $27 \%$ & $27 \%$ & $10 \%$ & $16 \%$ & \\
\hline Strongly Disagree & $5 \%$ & $8 \%$ & $2 \%$ & $7 \%$ & $8 \%$ & $0 \%$ & $0 \%$ & \\
\hline Don't Know & $7 \%$ & $5 \%$ & $15 \%$ & $6 \%$ & $6 \%$ & $15 \%$ & $12 \%$ & \\
\hline My involvement in & JRC has help & ed my own & standing in the & University & & & & \\
\hline Strongly Agree & $7 \%$ & $10 \%$ & $7 \%$ & $10 \%$ & $10 \%$ & $2 \%$ & $16 \%$ & \\
\hline Agree & $20 \%$ & $27 \%$ & $22 \%$ & $35 \%$ & $18 \%$ & $22 \%$ & $36 \%$ & \\
\hline Disagree & $22 \%$ & $31 \%$ & $22 \%$ & $10 \%$ & $27 \%$ & $38 \%$ & $24 \%$ & \\
\hline Strongly Disagree & $8 \%$ & $6 \%$ & $13 \%$ & $0 \%$ & $16 \%$ & $7 \%$ & $4 \%$ & \\
\hline Don't Know & $24 \%$ & $26 \%$ & $35 \%$ & $45 \%$ & $29 \%$ & $31 \%$ & $20 \%$ & $\mathrm{~T}$ \\
\hline
\end{tabular}

p-value $\mathrm{T} \mathrm{p}<.10 * \mathrm{p}<.05,{ }^{*} \mathrm{p}<.01,{ }^{* * *} \mathrm{p}<.001$ 
Eighty-seven percent of the faculty respondents indicated that their students have reasonable expectations of faculty member's involvement in their UR experience. This response did not vary significantly by faculty gender or rank. Finally, $78 \%$ percent of the faculty respondents strongly disagreed or disagreed with the following statement, "My students expect me to be more involved with their research than is feasible." Again, the responses to this question did not vary significantly by faculty rank or gender.

URC Mentoring and Faculty Personal and Professional Development: The majority of respondents were positive about their experiences as an UR mentor (Table 5). Seventy-seven percent of all participants indicated that they gained personal satisfaction from serving as an UR mentor. Seventy-two percent of the survey participants disagreed or strongly disagreed with the statement, "I have not found any benefit to my involvement in URC." When asked about their views of mentoring students during UR and their lives at the university, we found little variation in faculty members' answers by gender or rank.

When faculty members were asked whether they agreed with the following statement, "If a reduced course load was offered I would take it," $23 \%$ of faculty strongly agreed with this statement. The results did not vary significantly by gender but they did vary by rank $(\mathrm{p}<.05)$. Sixty percent of full professors, $25 \%$ of associate professors and $24 \%$ of assistant professors strongly agreed with this statement.

Twenty seven percent of the faculty respondents agreed with the statement, "My involvement in URC has helped my own standing in the university." Once again, the results did not vary significantly by faculty gender but did vary by faculty rank $(\mathrm{p}<.10)$. Forty-five percent of full professors strongly agreed or agreed with this statement compared with $28 \%$ of associate professors and $24 \%$ of assistant professors.

\section{QUALITATIVE RESULTS}

Qualitative data were gathered from two open-ended questions: (1) "In a very brief statement (not more than one or two sentences) summarize the most memorable aspect of your involvement in URC (Undergraduate Research Conference)" and (2) "Please provide any additional feedback on your experience with URC," were analyzed by three faculty researchers and two student researchers. Responses were reviewed as a whole and a winnowing process was used to identify themes. Key words and phrases for themes were coded and collated. The research team looked for themes and discrepancies in the qualitative data. Each discrepancy that arose was discussed in detail by the research team to ensure that there was unanimous agreement regarding the interpretation and resulting classification of the qualitative data.

Responses were generally positive; 89 out of 92 responses to the "most memorable" question were positive, with three of the four negative comments indicating disappointment with small audience numbers at student presentations during the conference. Three clear themes emerged from the key words and phrases about faculty's most memorable aspects of their UR involvement. Faculty mentors felt that UR enhanced student learning. They had a strong sense of accomplishment when the students' presented their research. The strongest theme was that the faculty mentors were very impressed by the quality of the students' presentations.

First, faculty mentors felt their participation in UR enhanced their students' learning. Forty-one out of 92 open-ended responses followed this theme; one faculty member wrote, "Mentoring URC projects is an excellent way of relating to your students and productively challenging them. It allows them to explore their own potential, discovering both their abilities and limits." In particular, faculty cited their benefits to students in learning about the research process. One faculty wrote, "It is wonderful to get to know students in this context and be part of their being able to "do" science. It is like Christmas, watching them unwrap the process of science and how that experience changes them - and I get to be there!!"

The second theme that emerged from the qualitative data was how faculty experience a strong level of satisfaction in their students' accomplishments. Forty-five out of 92 responses included comments that indicated pride, and that mentoring students was rewarding to them personally. Several mentioned specifically their pride in seeing their student present their work in a professional manner. One faculty mentor wrote, "Seeing my students 
presenting in a professional conference setting, and knowing that I helped them achieve something "extra" during their time at UNH, is very rewarding."

Faculty recognize, and take pride in, their part in making URC successful at UNH as well, citing their time on planning committees as well as pride in the event as a whole. One faculty noted that the most memorable aspect was, "... having students tell me that the undergraduate research opportunity was their most valuable UNH experience." Another specifically said URC had increased their pride in UNH and yet another wrote, "URC is one of the most rewarding weeks in the whole academic year for me."

The third theme that emerged from the 92 responses to the question regarding the most memorable aspect of UR was the quality of the research and professional presentations given by students. Many faculty marveled at the high quality, significant research, "I am always impressed by the transformation the students undergo....presenters who have interesting and original contributions to make to a body of disciplinary knowledge, sometimes with quite practical applications." Another faculty member noted, "The quality of the URC is very impressive and the students realize that and feel honored to be part of that experience." Some faculty indicated that their students' work also would be presented at national conferences and/or be published in professional journals.

The request for additional feedback yielded a wider variety of responses. A few (11 out of 52) were formative in nature, with suggestions for improving the registration process or presentation venues. Several responses (10 out of 52) questioned some of the assumptions made about undergraduate research by the survey. Most of these questions were from faculty in the humanities and those who mentor undergraduate students in other ways, such as with honors theses or through the McNair Graduate preparation program, and they questioned why the survey questions were focused more specifically on the students who participated in the URC events rather than other presentation venues.

Twelve of the 52 responses expanded upon the time commitment questions of the survey. Seven of these reiterated that they felt the time commitment involved in mentoring UR students was too great, and that there should be meaningful incentives (such as a reduction in teaching load) for faculty involved in UR. In contrast, the remaining five comments about time commitment expressed the opposite opinion, citing the time spent with undergraduates in research projects as productive or as an integral part of their jobs as faculty. One faculty member summed up this thought, "I consider undergraduate research to be a vital part of my overall research effort, and that undergraduate research allows me to leverage my work and my graduate student's work to accomplish more research than we could complete otherwise. So there is not a trade off. Any time that I spend with the students is more than made up for with increased research productivity."

\section{DISCUSSION}

Overwhelmingly, the faculty across the campus, independent of college, rank or gender, saw great benefits to mentoring a student engaged in UR. Faculty felt they could relate to students better in their classes and they gained personal satisfaction in supporting a student through the research process. There was a slight trend for female faculty members to feel that UR hindered progress on their research agenda, however, the faculty found mentoring an undergraduate student to be, on the whole, a very positive experience.

Most faculty survey participants found mentoring undergraduates helped them to relate to students better. The full professors found this aspect of mentoring to be especially appealing, the associate/assistant professors less so. There could be several reasons for full professors to find undergraduate research as a productive way to relate to their students. Full professors tend to be older (on average twenty years older than assistant professors as determined by Institutional Research and Assessment at UNH) and, due to administrative responsibilities, often teach fewer courses than other faculty. Having a project in common with undergraduate students could stimulate discussions between the professors and students, giving full professors greater insight into the lives and perspectives of their students.

In this study, forty-five percent of the full professors thought that mentoring undergraduate students enhanced their standing at the university. Full professors, more so than assistant and associate professors, are at an 
ideal stage in their career to serve as mentors to undergraduate students. Their research agendas are well-established and they have taken on leadership roles within the communities of their disciplines. Mentoring of undergraduate students by full professors fits an apprentice-style learning advanced by social constructivism (Giroux, 1988; Shor, 1987). The expert mentor takes into account students' own ways of making meaning and sees research as a negotiated, social and contextual process rather than knowledge being transmitted from the expert to the novice.

One of the themes found from the open-ended questions in the surveys supports the idea that faculty are developing some sort of apprentice style relationship with their students. In the open-ended question regarding the most memorable aspect of the UR experience, half of the faculty across the disciplines stated it was watching their students conduct such high quality research and presentations. Hunter, Laursen and Seymour (2007), in an ethnographic study of faculty and undergraduate science majors engaged in undergraduate research experiences at four colleges, found faculty developed this apprentice-style relationship. While the students emphasized their personal and intellectual development during the research experience, the faculty framed student gains as part of professional socialization into the sciences.

Faculty indicate that they enjoy developing a mentoring relationship with an undergraduate student, supporting that student through the research project, and watching the student present his/her research, and that the process results in a high level of personal satisfaction. However, with some faculty enhancing faculty teaching or increasing research productivity seems to be loosely coupled at best. Some faculty that mentor undergraduates through a research experience do not seem to think it is part of their explicit job responsibilities but feel a drive to support a novice's socialization into their community of practice. Since this survey was not sent to members of the faculty that do not mentor students, we do not know why those faculty decided not to mentor undergraduate students. This is a question that needs to be pursued further.

There was a small but significant difference in the way female faculty and male faculty viewed the possible impact of mentoring on their research agenda, even though overall both genders thought that mentoring an undergraduate student through an inquiry-based project was a positive experience. Some female faculty felt mentoring undergraduates in a research experience hindered their ability to work on their own research, though over $60 \%$ did not think it hindered them. There are several plausible explanations why this gender difference might occur. Given that the results do not vary according to rank, male professors may be less willing to take on students that do not, or cannot, work on their ongoing research projects, or female faculty members may be more willing to work outside their research interests to help students. More research will need to be done to explore the underlying causes for small but interesting gender difference.

\section{CONCLUSION}

The faculty at the University of New Hampshire who mentor undergraduate student research take great pride and overall are very satisfied with mentoring students who later present results in the undergraduate research conference. While there have been numerous studies on students' experiences and perceptions of the benefits to participating in undergraduate research (Russell, 2005; Bauer \& Bennett, 2003; Lopatto, 2004), there are fewer studies examining the motivations of faculty to mentor those students. Our research supports and furthers the research of Hunter, Laursen and Seymour (2007) with science, technology, engineering and mathematic faculty and their students. When asked to reflect on their research experience, the faculty framed student gains as an important part of professional socialization into the sciences. The present study, which surveyed faculty across colleges and disciplines, found a similar trend in faculty members' answers. However, the full professors were found to feel that participating in undergraduate research helped them to relate with students more strongly and increased their standing with the students. They felt participating in undergraduate research experiences was a way to connect with their students. This perception is supported by our analysis of the student experience with UR which indicates that students grow intellectually and develop confidence in ways that are different from their traditional classroom experiences (see Potter et al., in review). 


\section{FUTURE RESEARCH}

This study focused on the reasons why faculty members mentored undergraduate students through their research projects. The results can help us better understand how to support these dedicated faculty in appropriate and rewarding ways. Faculty members who do not mentor undergraduate students through a research project also need to be studied. What are the reasons, barriers or obstacles that prevent this group of faculty from working with undergraduate students or from seeing the project through to presentation at the URC successfully? This information might suggest ways to enhance their ability to engage in undergraduate research and fulfill the Boyer Commission's plan to promote research-based learning as the standard at institutions of higher education (1998).

One intriguing result from this study is the greater number of female than male faculty that feel engaging in URC experiences might hinder their research agenda. The significant difference between men and women warrants further study. For instance, do women faculty mentor differently than men? Are men more likely to work with students on their existing projects whereas women are more likely to work on student projects outside their own research areas that require a larger time investment? Another interesting observation is that the mentors who participated in our study did not think that mentoring URC students should be a requirement for tenure. This suggests that the possibility of differences in mentoring style (and/or participation) and faculty rank which should be explored along with investigating in more detail the differences in gender that were observed.

\section{AUTHOR INFORMATION}

Dr. Sharyn J. Potter is an associate professor in the Department of Sociology at UNH. She has served on the UNH Undergraduate Research Conference (URC) Planning Committee for the past 7 years. For the past four years she has chaired the URC evaluation committee. She has studied how policy change impacts organizations, providers and clients. For the past six years Dr. Potter has helped lead the development and evaluation efforts of the Know Your Power Bringing in the Bystander Social Marketing Campaign. She is part of a research team that has received funding from the NIJ, DOJ and CDC.

Dr. Eleanor Abrams is an associate professor in the Department of Education at the University of New Hampshire. Dr. Abrams has edited one book and numerous articles investigating models of inquiry-based education in public education, effective instructional methods to teach science to undergraduate students and the effects of engaged scholarship on faculty development.

Dr. Lisa Townson currently serves as the Assistant Director for programs for University of New Hampshire Cooperative Extension. She has been a specialist in program development and evaluation for UNH Cooperative Extension for six years and has been involved on the UNH Undergraduate Research Conferences Evaluation subcommittee for four years. Lisa has been involved in numerous web-based survey research projects and additional areas of research interest include higher education, specifically university engagement and outreach scholarship.

Dr. Julie E. Williams is associate vice president for research and outreach scholarship at the University of New Hampshire. Her primary responsibilities are leading the institution's public engagement mission, building collaborative interdisciplinary and multi-institutional research teams that have external benefit, and creating faculty professional development opportunities for engaged scholarship. The UNH undergraduate research conference (URC) reports to her office. Over the last eight years her team has lead the transformation of the URC. She leads institutional and unit-level strategic planning efforts. She received her doctorate in clinical psychology from the University of Tennessee-Knoxville.

\section{REFERENCES}

1. Boyer commission on education undergraduates in the research university. Reinventing undergraduate education: A blueprint for America's research universities. (1998). Stony Brook: State University of New York.

2. Bauer, K., \& Bennett, J.S. (2003). Alumni perceptions used to assess undergraduate research experience. The Journal of Higher Education, 74(2), 210-230. 
3. Braxton, J.M. (1996). Contrasting perspectives on the relationship between teaching and research. New Directions for Institutional Research, 90, 5-14.

4. Collins, L.H. (2006). Does research experience make a significant difference in graduate admissions? Psi Chi Journal of Undergraduate Research, 5(2), 1-4.

5. Ekrut, S., \& Mokros, J. R. (1984). Professors as models and mentors for college students. Educational Research Journal, 21, 339-417.

6. Feldman, K. (1987). Research productivity and scholarly accomplishment of college teachers as related to their instructional effectiveness: A review of exploration. Research in Higher Education, 26, 227-298.

7. Foertsch, J.A., Millar, S.B., Squire, L.L., \& Gunter, R. L. (1997). Persuading professors: A study of dissemination of education reform in research institutions (Vol. 5). Madison, WI: University of MadisonWisconsin, LEAD Center.

8. Folse, K. A. (1991). Ethics and the profession: Graduate student training. Teaching Sociology, 19, 344-350.

9. Gafney, L. (2005). The role of the research mentor/teacher. Journal of College Science Teaching, 34(4), 52-56.

10. Giroux, H. (1988). Schooling and the struggle for public life: Critical pedagogy in the modern age. Minneapolis: University of Minnesota Press.

11. Hakim, T. (1998). Soft assessment of undergraduate research: Reactions and student perceptions. Council of Undergraduate Research Quarterly, 18, 189-1192.

12. Hattie, J., \& Marsh, H.W. (1996). The relationship between research and teaching-a meta-analysis. Review of Educational Research, 66, 507-542.

13. Hunter, A., Laursen, S.L., \& Seymour, E. (2007). Becoming a scientist: The role of undergraduate research in students' cognitive, personal, and professional development. Science Education, 91, 36-74.

14. Jenkins, A., Healey, M., \& Zetter, R. (2007). Linking teaching and research in disciplines and departments. Retrieved January 12, 2009, from http://www.heacademy.ac.uk/resources/publications.

15. Lancy, D.F. (2003). What one faculty member does to promote undergraduate research. New Directions for Teaching and Learning, 93, 87-92.

16. Lopatto, D. (2003). The essential features of undergraduate research. Council on Undergraduate Research Quarterly, March, 139-142.

17. Lopatto, D. (2004). Survey of undergraduate research experiences (sure): First findings. Cell Biology Education, 3, 270-277.

18. Marsh, H. W., \& Hattie, J. (2002). The relation between research productivity and teaching effectiveness: Complementary, antagonistic, or independent constructs? The Journal of Higher Education, 73(5), 603641.

19. Monte, A. (2001). Mentor expectations and student responsibilities in undergraduate research. Council of Undergraduate Research Quarterly, December, 66-71.

20. Munoz-Dunbar, R., \& Stanton, A.L. (1999). Ethnic diversity in clinical psychology: Recruitment and admission practices among doctoral programs. Teaching of Psychology, 26, 259-263.

21. National Science Foundation. (2000). NSF GPRA Strategic Plan, FY 2002-2006 (NSF Publication 0104). Retrieved January 12, 2009, from http://www.nsf.gov/publications/pub summ.jsp?ods key=nsf0104.

22. Potter, S., Abrams, E., Towson, L., Williams, J., \& Wake, C. I. (in review). Intellectual growth for undergraduate students and faculty: Evaluation results from an undergraduate research conference. Journal on Excellence in College Teaching.

23. Russell, S. H. (2005). Evaluation of NSF support for undergraduate research opportunities: 2003 NSF program participant survey (draft final report to the NSF). Retrieved January, 2007, from http://www.sci.com/policy/csted/reports.

24. Schowen, K.B. (1998). Research as a critical component of the undergraduate education experience, assessing the value of research in the chemical sciences: Report of a workshop. Washington, DC: National Academy Press.

25. Seymour, E., Hunter, A., Laursen, S. L., \& Deantoni, T. (2004). Establishing the benefits of research experiences for undergraduates in the sciences: First findings from a three year study. Science Education, 88(4), 493-534.

26. Shor, I. (1987). Critical teaching and everyday life. Chicago: University of Chicago Press.

27. Waldeck, J. H., Orrego, V. O., Plax, T. G., \& Kearney, P. (1997). Graduate student/faculty mentoring relationships: Who gets mentored, how it happens and to what end. Communication Quarterly, 45, 93-109. 
28. Zydney, A.L., Bennett, J.S., Shahid, A., \& Bauer, K.W. (2002). Faculty perspectives regarding the undergraduate research experience in science and engineering. Journal of Engineering Education, 91, 291297.

\section{NOTES}

